\title{
Study on the Mechanism of Biotreatment of Coke-making Wastewater
}

\author{
Jianwei Zhu*, Bin Wu \\ Hangzhou Institute of Environmental Protection, Chinese Coal Technology \& Engineering Group, Hangzhou, China \\ Email address: \\ 383038109@qq.com (Jianwei Zhu),timmy0709@163.com (Bin Wu) \\ ${ }^{*}$ Corresponding author \\ To cite this article: \\ Jianwei Zhu, Bin Wu. Study on the Mechanism of Biotreatment of Coke-making Wastewater. American Journal of Water Science and \\ Engineering. Vol. 5, No. 2, 2019, pp. 96-104. doi: 10.11648/j.ajwse.20190502.16
}

Received: June 5, 2019; Accepted: July 2, 2019; Published: July 12, 2019

\begin{abstract}
Based on a large number of experimental data, this paper puts forward a three-stage hypothesis of biochemical degradation of coking wastewater. And studies on the biochemical degradation kinetics in various stages through laboratory experiments have been made. In these studies, a new concept has been proposed, that of substances present in coking wastewater that can be biochemically treated to produce ammonia nitrogen. And this class of substances, we define and call BN for short. BN's meaning is to produce ammonia nitrogen in the process of biochemical treatment. The relationship between COD, the substances that can biotreatedly produce ammonia nitrogen $(\mathrm{BN})$, ammonia nitrogen and time in biochemical degradation is revealed. In the first stage of biochemistry is the removal of a large amount of organic pollutants, so that the strong smell of the wastewater is removed while most of the COD is removed. In the second stage of biochemistry is the removal of substances that produce ammonia nitrogen $(\mathrm{BN})$. These increases the ammonia nitrogen in the wastewater. In the third stage of biochemistry is degradation of ammonia nitrogen, so that ammonia nitrogen meets the emission standard. The mathematical model of biochemical degradation kinetics is proposed. The mathematical model consists of 12 formulas. The first stage has one formula, the second stage has five formulas, and the third stage has six formulas. The hydraulic retention time of biochemical treatment tank at different stages can be calculated by these formulas. Based on the proposed mathematical model, this paper illustrates the significance of the three-stage theory to the design and operation of the biochemical treatment of coking wastewater. At the same time, we can see the importance of the new concept of BN.
\end{abstract}

Keywords: Biochemical Treatment of Coking Wastewater, Three-Stage Hypothesis, New Concept of BN, Biochemical Degradation Kinetics, Mathematical Model

\section{Introduction}

Coke is an important raw material in steel production, which is an ideal fuel and reducing agent. According to preliminary statistics from the China coking industry association, total coke production in 2008 was $327 \mathrm{~m}$ tons, accounting for $60 \%$ of the global total [1]. Coal coking industrial wastewater is one of the important pollutants in China's coal chemical industry wastewater. The wastewater is complex, highly toxic and very dark. In the analysis and detection of the components of coal processing wastewater, Lingdong Kong et al. discussed 244 kinds of organic pollutants by GC/MS. Among them, 129 kinds of acid extraction liquid, 115 kinds of alkali neutral extraction liquid were detected in the influent. 37 kinds of phenols were analysed, and these concentrations were high. Secondly, there were heterocyclic compounds such as pyridine, quinoline, aniline, benzene series, diphenyl, furan, carbazole, indole, hexane, naphthalene, thiophene, etc. and there were a small amount of alcohol, aldehydes, acids, vinegar, aromatic hydrocarbons such as fluoranthrene, pyrene, and naphthacene, benz [c] anthracene, benzophenanthrene, benzo [j] fluoranthene, benzoapyrene and so on [2]. Degradation of these pollutants mainly adopts the kind of biochemical treatment process. Biochemical treatment is the use of microbial metabolism to make waste organic pollutants in the water into $\mathrm{CO}_{2}$, water and other harmless substances to realize wastewater purification [3]. For the biochemical treatment of coal chemical wastewater, there are mainly several aspects of 
research. Wang Chunrong et al. has isolated the strain used in the experiments from actual coking wastewater treatment system. Based on physiological-biochemical determination, it is identified prilimarily as Serratia sp. [4]. Dev Raj Joshi et al. studied performance and microbial community composition in a long-term sequential anaerobic-aerobic bioreactor operation treating coking wastewater [5]. PENG Pai has applied sludge bacteria agent to coking wastewater. The results showed that the average removal rate of COD increased by $18 \%$ compared to the activated sludge system by adding sludge bacteria agent; PCR-DGGE results showed that the kind of microbes in the biochemical system became more abundant, the varieties of microorganisms varied from 14 to 23 [6].

Chongwei Cui et al. has studied the biological treatment of hydrolytic acidification - anoxia - aerobic combination. The treatment effect of coal gasification wastewater is better than that of oil removal, phenol removal, ammonia distillation, three-stage activated sludge biological treatment process [7]. Li Huiqiang, Han Hongjun, Du Maoan, et al. used MBBR method to treat Lurgi fixed bed gasification wastewater. The COD decreased by $81 \%$, and the phenol and ammonia decreased respectively by $89 \%, 93 \%$ [8]. Zhao Qian et al. made research on new method. The PACT method was applied to the short-cut biological denitrification process, and the total removal rate of general nitrogen of the system increased from $43.8 \%-49.6 \%$ to $68.8 \%-75.8 \%$ [9]. $\mathrm{A}_{1}-\mathrm{A}_{2}-\mathrm{O}$ process is the innovation process on the basis of A-O process by adding anaerobic section. Anaerobic section can be better performed to treat coking wastewater by hydrolytic acidification. The results showed that $\mathrm{NH}_{3}-\mathrm{N}$ removed by $\mathrm{A}_{1}-\mathrm{A}_{2}-\mathrm{O}$ process and denitrification are better than $\mathrm{A}-\mathrm{O}$ process, but the effluent COD is still very high [10]. Xin Zhou et al. studied O-O-A-A biofilm treatment of coking wastewater, and then in the pilot - scale test. The hydraulic retention time was $116 \mathrm{~h}$, The removal rate of COD and $\mathrm{NH}^{4+}$. $\mathrm{N}$ reached $92.3 \%$ and $97.8 \%$ respectively [11]. Maranón E et al. applied SBR process to treat coking wastewater, reaction in a CSTR (continuous stirred tank reactor), ammonia stripping efficiency $96 \%$, hydraulic retention time $115 \mathrm{~h}$, effluent thiocyanates, phenols removal rate is $98 \%, 99 \%$ [12]. Cui-ping LIU et al. introduced the treatment technology of $350 \mathrm{~m}^{3} / \mathrm{h}$ coking waste water in Baotou Coking Coal Chemical Plant, and suggusted that the hydraulic retention time of biochemical system was better controlled at $45 \sim 50 \mathrm{~h}$ [13]. Jin Tao et al. introduced the combined treatment process of pretreatment -biochemical treatment -advanced treatment for coking waste water in an Inner Mongolia coking plant, and reported that the hydraulic retention time of biochemical system was $117 \mathrm{~h}$ [14].

It can be seen from the above studies that the mechanism and kinetics of biochemical treatment of coking wastewater are still vacant. And if biochemical mechanism research on each pollutant were studied, it would have been a huge work, and would not be necessary. From a large number of engineering practice experience and data, the mechanism of coking wastewater biochemical treatment can be a comprehensive judgment, and then, on these basis, the biochemical mechanism of in-depth research is of great practical significance. it can guide design and operation. In this paper, the exploration on the mechanism of biochemical treatment of coking wastewater was made, and the ideas of the three stages of degradation were put forward. Based on biochemical reaction experiment, kinetics at each stage was studied. The mechanism of biochemical treatment of coking wastewater is different from that of domestic sewage biochemical treatment [15-16]. Coking wastewater contains a large amount of toxic substances. After the raw water enters the biochemical system, there is a certain amount of activated sludge to die, and it acts as a depressant. Therefore the activated sludge needs to be domesticated so that the degradation rate can be maximized, and then the biochemical reaction follows the Michaelis-Menten equation [17]. These makes the process of studying dynamics difficult. In addition, the study of kinetics should be carried out on the premise that biochemical degradation mechanism is clear. In other words, the kinetics study should be based on experiments.

\section{Materials and Methods}

Idea of three stages of biodegradation of coking wastewater.

In the process of biochemical degradation of coking wastewater, a large number of laboratory studies have been conducted to find out:

The coking wastewater contains organic pollutants, which are toxic to activated sludge. In addition, there are pollutants that produce ammonia nitrogen after biochemical action. In the process of biochemical degradation of coking wastewater, there are three stages.

(1) In the first stage of biochemistry, a large amount of organic pollutants (COD) are removed, meanwhile, the heavy odor of the wastewater is also removed [18].

(2) In the second stage of biochemistry, the removal of substances that produce ammonia nitrogen raises the ammonia nitrogen in the waste water.

(3) In the third stage of biochemistry, ammonia nitrogen is degraded to meet the emission standard [19].

Based on the above ideas, the following experiments are designed and made.

\subsection{Research on the First Stage of Biochemical Treatment of Coking Wastewater}

\subsubsection{Raw Water Quality}

The coking wastewater was taken from waste water produced by the coking plant.

A. Raw coking wastewater: $\mathrm{pH}=8.02, \mathrm{COD}=3149 \mathrm{mg} / \mathrm{L}$, $\mathrm{NH}_{3}-\mathrm{N}=151 \mathrm{mg} / \mathrm{L}$,

B. Raw coking wastewater: $\mathrm{pH}=8.25, \mathrm{COD}=3680 \mathrm{mg} / \mathrm{L}$, $\mathrm{NH}_{3}-\mathrm{N}=141 \mathrm{mg} / \mathrm{L}$,

\subsubsection{Experimental Methods}

A. In no. 1 bucket, $62 \mathrm{~L}$ of coking wastewater and $68 \mathrm{~L}$ of tap water were mixed, and original coking wastewater was from $\mathrm{A}$ : $\mathrm{COD}=3149 \mathrm{mg} / \mathrm{L}$, ammonia nitrogen $=151 \mathrm{mg} / \mathrm{L}$; The activated sludge was added (taken from the coking wastewater 
treatment secondary sedimentation tank, which has been domesticated and cultured) for biodegradation. Determination of COD and ammonia nitrogen was made each time.

B. In no. 2 bucket, 70L of coking wastewater and 70L of tap water were mixed, original coking wastewater was from B: $\mathrm{COD}=3680 \mathrm{mg} / \mathrm{L}$, ammonia nitrogen $=141 \mathrm{mg} / \mathrm{L}$; The activated sludge was added (taken from the coking wastewater treatment secondary sedimentation tank, which has been domesticated and cultured) for biodegradation. Determination of COD and ammonia nitrogen was made each time.

\subsection{Research on the Second Stage of Biochemical Treatment of Coking Wastewater}

In the first stage, most of the COD was degraded, and all phenolic substances were removed. But some of the substances that produce ammonia nitrogen (SPA) play an important role in this stage. This is the kind of substance that we use the abbreviation $\mathrm{BN}$ (biotreated ammonia nitrogen) for.

\subsubsection{Raw Water Quality}

Raw wastewater: $\mathrm{pH}=10.14, \quad \mathrm{NH}_{3}-\mathrm{N}=425 \mathrm{mg} / \mathrm{L}$, $\mathrm{COD}=4333 \mathrm{mg} / \mathrm{L}, \mathrm{BN}=540 \mathrm{mg} / \mathrm{L}$,

\subsubsection{Experimental Methods}

The experiment was carried out in three stages (stageA, stage $B$ and stage $C$ ), and the strains were divided into three categories. The first kind removes COD, the second kind removesBN, and the third kind removes ammonia nitrogen. Different kinds of strains were domesticated and enriched for different stages of experiments after some peroids.

Stage A: $200 \mathrm{~mL}$ of the raw wastewater adjusted the $\mathrm{pH}$ to neutral, was taken and added to the $300 \mathrm{~mL}$ mixture liquid containing activated sludge with the last biochemical degradation. Then the biotreatment was initiated. In the stage A, Biochemical degradation was completed until the phenol smell was removed. Stood for Sedimentation and sediment stratification. Took the supernatant $200 \mathrm{~mL}$ as the original water of Stage B. The remaining $300 \mathrm{~mL}$ was used as the next experimental strain. And later, repeated the process in following round.

Stage B: $250 \mathrm{~mL}$ of the original waste water was from the accumulated supernatant completed in the Stage A reaction, and the $250 \mathrm{~mL}$ of biotreated supernatant of stage A was added to the $250 \mathrm{~mL}$ mixture liquid containing activated sludge that had completed the last round of stage B biochemical degradation, Then the biotreatment was initiated, and the stage $\mathrm{B}$ biochemical degradation was completed until the $\mathrm{BN}$ was removed. Stood for Sedimentation and sediment stratification. Took the supernatant $250 \mathrm{~mL}$ as the original water of Stage C. The remaining $250 \mathrm{~mL}$ was used as the next experimental strain. And later, repeated the process in following round.

Stage C: $250 \mathrm{~mL}$ of the original waste water was from the supernatant completed in the Stage B reaction, and the $250 \mathrm{~mL}$ of biotreated supernatant of stage B was added to the $250 \mathrm{~mL}$ mixture liquid containing activated sludge that had completed the last round of stage $\mathrm{C}$ biochemical degradation, Then the biotreatment was initiated, and the stage $\mathrm{C}$ biochemical degradation was completed until ammonia nitrogen was removed. Stood for Sedimentation and sediment stratification. Discharged the supernatant liquid $250 \mathrm{~mL}$. The remaining $250 \mathrm{~mL}$ was used as the next experimental strain. And later, repeated the process in following round.

\subsection{Study on the Third Stage of Biochemical Treatment of Coking Wastewater}

\subsubsection{Raw Water Quality}

$\mathrm{pH}=9.46, \mathrm{NH}_{3}-\mathrm{N}=1351 \mathrm{mg} / \mathrm{L}, \mathrm{COD}=2658 \mathrm{mg} / \mathrm{L}, \mathrm{BN}=83.2$ $\mathrm{mg} / \mathrm{L}$.

\subsubsection{Experimental Methods}

Took $300 \mathrm{~mL}$ of the raw waste water, mixed with $200 \mathrm{~mL}$ of the liquid containing activated sludge, the activated sludge was domesticated and cultivated, and then biodegradation was initiated. Determination of $\mathrm{BN}$, ammonia nitrogen and so on were made.

\section{Results}

\subsection{Research on the First Stage of Biochemical Treatment of Coking Wastewater}

A. In no. 1 bucket, the relationship between COD, ammonia nitrogen and time is shown in Figure 1.

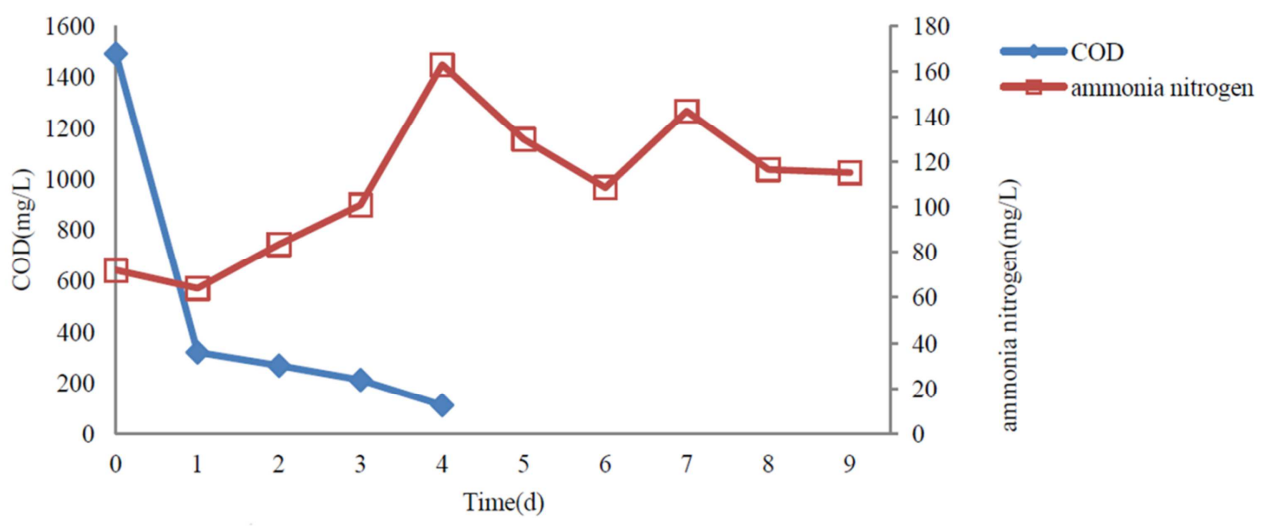

Figure 1. The relationship between COD and ammonia nitrogen and time in the first stage of biotreatment of coking wastewater. (No1 bucket). 
B. In no.2 bucket, the relationship between COD, ammonia nitrogen and time is shown in Figure 2.

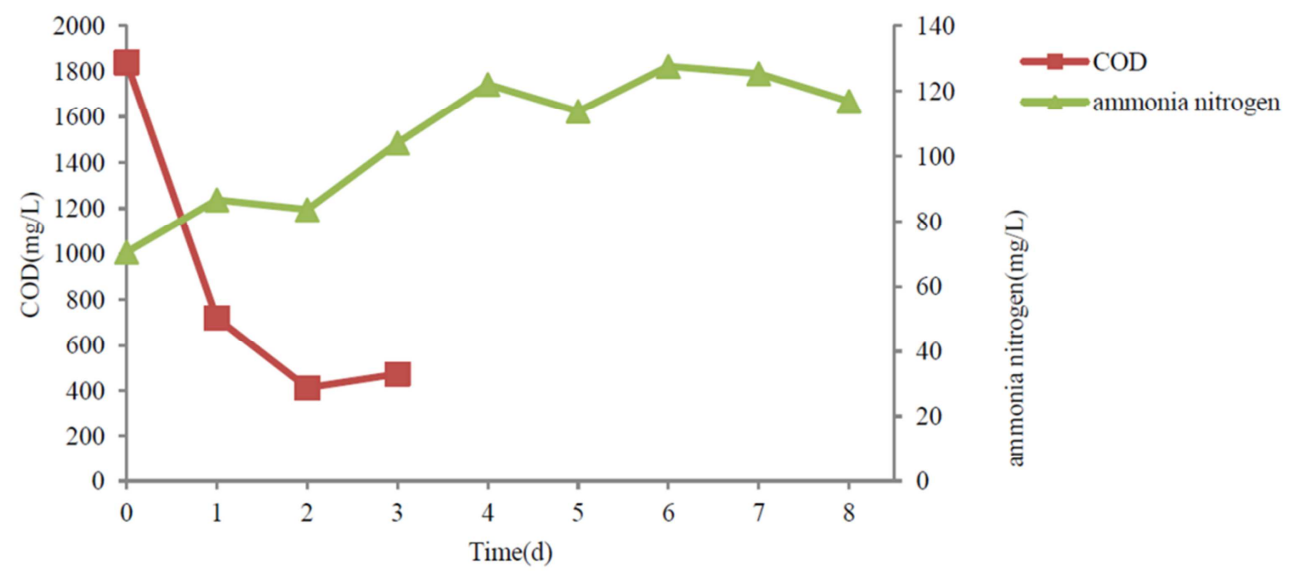

Figure 2. The relationship between COD and ammonia nitrogen and time in the first stage of biotreatment of coking wastewater. (No2 bucket).

The results showed that COD degradation was relatively fast in the previous period, and the decrease was not obvious after that. Ammonia nitrogen initially fell slightly. After that, ammonia decreased less and sometimes went up. This was a period of upward trend of the ammonia.

\subsection{Research on the Second Stage of Biochemical Treatment of Coking Wastewater}

Stage A:

As the olfactory threshold concentration of phenolic compounds and chlorophenol is $0.001-0.005 \mathrm{mg} / \mathrm{L}$, we can simply judge the COD removal by phenol smell removal in the stage A.

The relationship between COD removal (phenol smell removal) and time is shown in Table 1.

Table 1. Relation between COD removal (phenol smell removal) and time.

\begin{tabular}{llllll}
\hline Round & Time $(\mathbf{d})$ & $\mathbf{N H}_{3}-\mathbf{N}(\mathbf{m g} / \mathbf{L})$ & $\mathbf{B N}(\mathbf{m g} / \mathbf{L})$ & $\mathbf{C O D} \mathbf{( m g} / \mathbf{L})$ & Notes \\
\hline 1 & 0 & +170 & +216 & +1733.2 & Phenol smell disappeared \\
2 & 1 & & & & \\
& 0 & +170 & +216 & +1733.2 & Phenol smell disappeared \\
3 & 1 & +170 & +216 & +1733.2 & Phenol smell disappeared \\
\hline
\end{tabular}

The results showed that the degradation period of stage A was1 day.

Stage B:

The relationship between COD, ammonia nitrogen, BN and time in the second stage is shown in Figure 3.

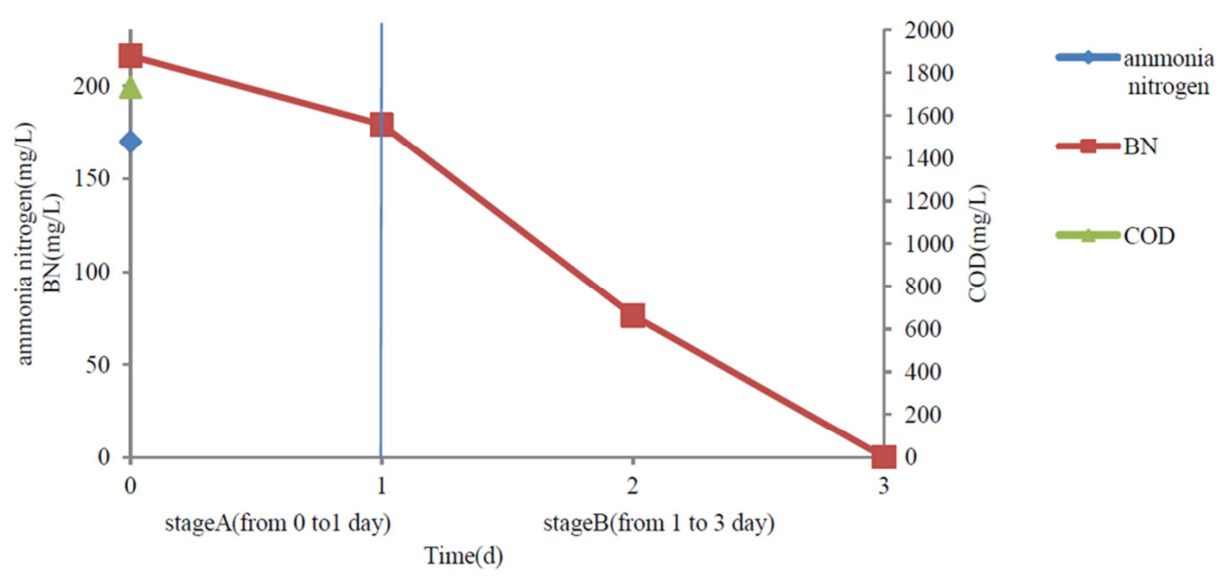

Figure 3. The relationship between COD, ammonia nitrogen, $B N$ and time in the second stage (from 1 day to 3 day).

The results showed that the degradation period of stage B was 2 days. 
Stage $C$ :

The relationship between COD, ammonia nitrogen, $\mathrm{BN}$ and time in the third stage is shown in Figure 4.

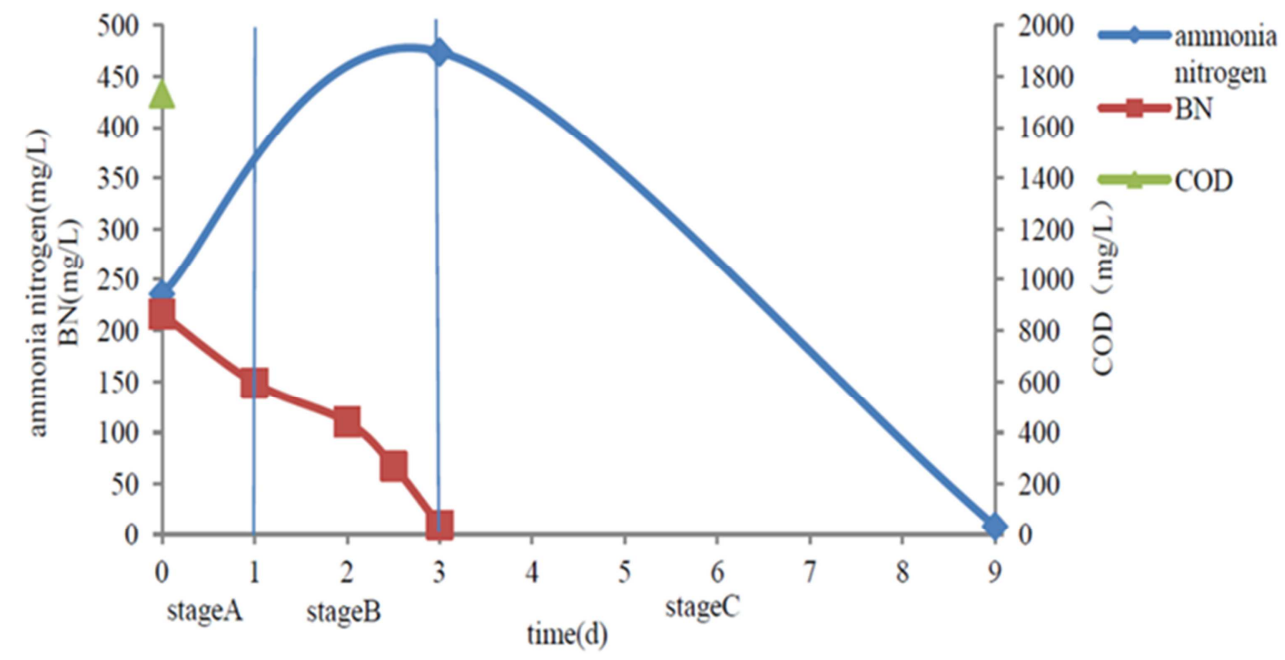

Figure 4. The relationship between COD, ammonia nitrogen, $B N$ and time in the third stage (from 3 day to 9 day).

The results showed that the degradation period of stage $\mathrm{C}$ was 6 days. The initial concentration of ammonia nitrogen was $474 \mathrm{mg} / \mathrm{L}$, and the concentration was $8.5 \mathrm{mg} / \mathrm{L}$ after treatment.

After several rounds, it can be calculated that the ammonia nitrogen of the original wastewater is $425 \mathrm{mg} / \mathrm{L}$, assuming that the $\mathrm{BN}$ : ammonia nitrogen $=1: 1, \mathrm{BN}$ produces ammonia nitrogen $540 \mathrm{mg} / \mathrm{L}$, and $425+540=965 \mathrm{mg} / \mathrm{L}$, in the stage $\mathrm{C}$, the initial concentration of ammonia nitrogen is $965 / 2=531$ $\mathrm{mg} / \mathrm{L}$ because that the $250 \mathrm{~mL}$ of biotreated supernatant of stage $\mathrm{B}$ was added to the $250 \mathrm{~mL}$ mixture liquid containing activated sludge that had completed the last round of stage $\mathrm{C}$ biochemical degradation. And the actual measured value of initial concentration of ammonia nitrogen is $474 \mathrm{mg} / \mathrm{L}$ in the stage C. Considering the $531-474=57 \mathrm{mg} / \mathrm{L}$, it is found that after several rounds of stage A and stage $\mathrm{B}$, the ammonia nitrogen is almostly not bio-degraded in the first and second stages. Though most of the phenols were removed on the first day, and the next day, the third day, due to the high level of $\mathrm{BN}$, it affected the degradation of ammonia nitrogen. Therefore, the biodegradation of ammonia is only activated when the BN is largely removed.

\subsection{Research on the Third Stage of Biochemical Treatment of Coking Wastewater}

Raw wastewater sample $300 \mathrm{~mL}$ was prepared to $500 \mathrm{~mL}$, $\mathrm{COD}=1595 \mathrm{mg} / \mathrm{L}$. The relationship between ammonia nitrogen, $\mathrm{BN}$ and time in the third stage is shown in Figure 5.

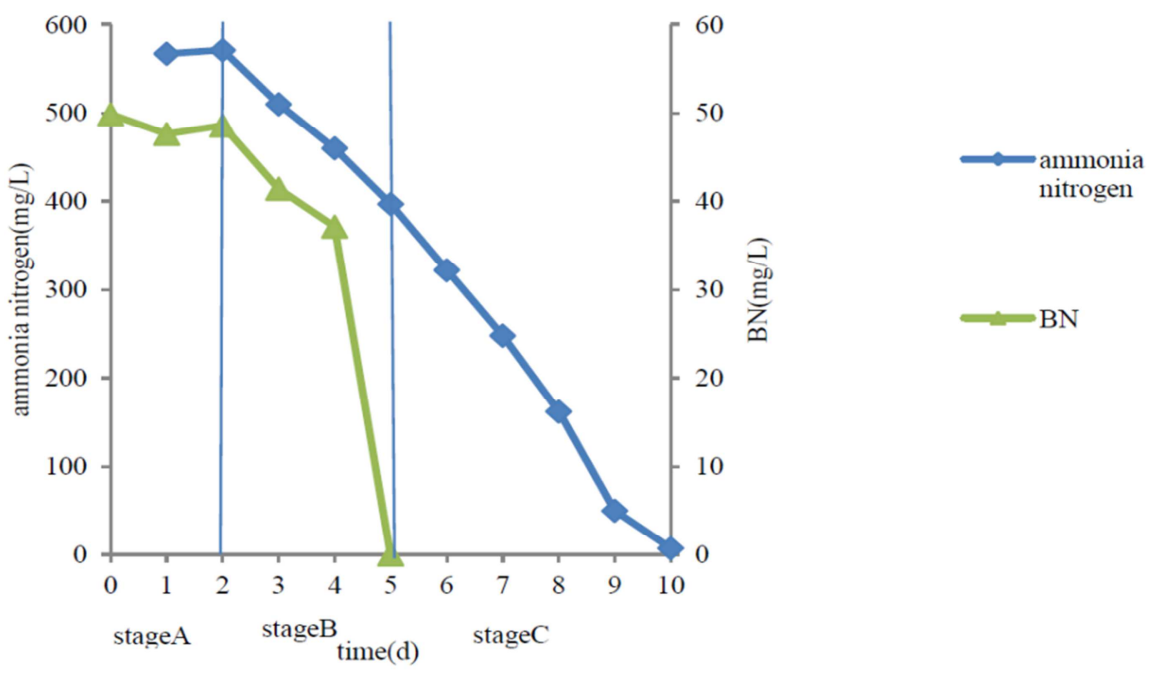

Figure 5. The relationship between ammonia nitrogen, $B N$ and time in the third stage.

The results show that the BN began to degrade after 2 days, biochemical degradation of phenolics affected the $\mathrm{BN}$, ammonia nitrogen began to degrade after 2 days, that phenolics affected the biochemical degradation of ammonia nitrogen. 


\section{Discussion}

\subsection{Discussion on the Characteristics of the First Stage of Biochemical Treatment of Coking Wastewater}

In the first stage of biochemical treatment of coking wastewater, the obvious characteristic is that COD is mostly removed and the phenol odor is removed, while ammonia nitrogen has not been removed, and sometimes it has gone up. A total of 113 species were detected in the effluent of biochemical treatment of coking wastewater, of which 35 were acid extractive fluid and 78 in alkali neutral group. The phenols in effluent was not detected, and pyridine, Quinoline, aniline, biphenyl, furan, carbazole and indole were removed, and there were some carboxylic acids, alcohols, alkanes, aromatic hydrocarbons, etc., they have a plenty of existing in the raw water, some like carboxylic acid, alkane and aromatic derivative is the intermediate product in the process of processing [2].

In coking wastewater, ammonia nitrogen can be produced with Kjeldahl nitrogen (except ammonia nitrogen) and nitrogen organic compounds, such as pyridine, indole, quinoline and nitrile, and so on. These kinds of material affect the whole process of biodegradation. So in the later phases of the first stage of biochemical treatment, such substances that can produce ammonia nitrogen should be studied on.

\subsection{Discussion on the Second Stage Characteristics of Coking Wastewater Biochemical Treatment}

The second stage of biochemical treatment of coking wastewater mainly removes BN. As can be seen from the experiment, the biochemical treatment, in the first stage which is in the process of removing phenol, cannot synchronously remove material to produce ammonia nitrogen $(\mathrm{BN})$ rapidy. According to the result 3.1, the biodegradation of the material which can produce ammonia nitrogen $(\mathrm{BN})$ has a lag period, that starts at the end of the first stage. This feature limits the degradation rate of biochemical treatment. This may also be due to the high concentration of pollutants in the first stage, which inhibits the second stage of the process. Only when the organic pollutants of the first stage are degraded to a certain level, the process of the second stage can begin.

\subsection{Discussion on the Characteristics of the Third Stage of Biochemical Treatment of Coking Wastewater}

The third stage of biochemical treatment of coking wastewater mainly removes ammonia nitrogen. In the whole biochemical treatment process, the change of ammonia nitrogen is as following. In the first stage, when the COD removes, the ammonia nitrogen slightly decreases meanwhile. The amount of ammonia nitrogen removal can be calculated as: assume BOD:COD $=0.509: 1$, and the $100 \mathrm{~g}$ BOD removal needs consumption of $4.3 \mathrm{~g}$ ammonia nitrogen. In the second stage, the amount of ammonia nitrogen produced by the $\mathrm{BN}$ is determined by the BN. So after the cumulative ammonia nitrogen reachs a certain level, the ammonia nitrogen will be biodegraded in the third stage.

\subsection{Hypothesis of Bio-degradation Kinetics of Coking Wastewater}

For a coking waste water, the determination of COD, BN and ammonia nitrogen was respectively carried out.

The first stage: removal of organic matter COD. Due to the second and the third stage, therefore, in this stage the degradation rate of COD is basically zero order reaction. The degradation rate of COD is $280 \mathrm{mgCOD} / \mathrm{gMLSS} * \mathrm{~d}$, and assume the $\mathrm{MLSS}=4000 \mathrm{mg} / \mathrm{L}, 280 \mathrm{mgCOD} / \mathrm{gMLSS} * \mathrm{~d}=$ $1120 \mathrm{mgCOD} / \mathrm{L} * \mathrm{~d}$. When biochemical degraded COD is less than $472 \mathrm{mg} / \mathrm{L}$, the second stage of biochemical degradation will begin.

The second stage: removal of substances that produces ammonia (BN). When the COD goes down to $472 \mathrm{mg} / \mathrm{L}$, the degradation rate of the $\mathrm{BN}$ will begin. And the degradation rate of $\mathrm{BN}$ is $9.23 \mathrm{mgBN} / \mathrm{gMLSS} * \mathrm{~d}$, which was $9.23 \mathrm{mgBN} / \mathrm{gMLSS} * \mathrm{~d}=36.92 \mathrm{mgBN} / \mathrm{L} . \mathrm{d}, \quad$ assuming $\mathrm{MLSS}=4000 \mathrm{mg} / \mathrm{L}$. And meanwhile, the COD continues to decrease. After that, the COD value remains within a small change range for a period of time. However, $\mathrm{BN}$ continues to biodegrade, and its degradation rate was accelerated to $22.411 \mathrm{mgBN} / \mathrm{gMLSS} * \mathrm{~d}$, assuming the $\mathrm{MLSS}=4000 \mathrm{mg} / \mathrm{L}$, then, $22.411 \mathrm{mgBN} / \mathrm{gMLSS} * \mathrm{~d}=89.64 \mathrm{mgBN} / \mathrm{L} * \mathrm{~d}$. When the $\mathrm{BN}$ breaks down to 0 , the biochemical process enters the third stage.

The third stage: removal of ammonia nitrogen. The amount of ammonia nitrogen is the initial concentration plus the ammonia nitrogen produced during $\mathrm{BN}$ degradation. The rate of oxidation is $19.4 \mathrm{mg}$ ammonia nitrogen /gMLSS*d, $19.4 \mathrm{mg}$ ammonia nitrogen $/ \mathrm{gMLSS} * \mathrm{~d}=77.6 \mathrm{mg} / \mathrm{L} * \mathrm{~d}$ (assuming the $\mathrm{MLSS}=4000 \mathrm{mg} / \mathrm{L}$ ). In addition, the degradation rate of denitrification after ammonia nitrogen oxidation is $32.5 \mathrm{mg}$ total nitrogen $/ \mathrm{gMLSS} * \mathrm{~d}$, and $32.5 \mathrm{mg}$ total nitrogen $/ \mathrm{gMLSS} * \mathrm{~d}=130 \mathrm{mg}$ total nitrogen /L.d (assuming the $\mathrm{MLSS}=4000 \mathrm{mg} / \mathrm{L})$.

\subsection{Mathematical Model of Biochemical Process Degradation Kinetics of Coking Wastewater}

(1) COD removal process:

Hydraulic retention time for COD removal $=\mathrm{La} /(\mathrm{NsX})$.

Where $\mathrm{La}$ is the Initial concentration of COD $(\mathrm{mg} / \mathrm{L})$;

Ns is the COD removal rate (mgCOD/mgMLSS*d)

$\mathrm{X}$ is the MLSS mixed liquor suspended solids (mg/L)

(2) Removal of BN process:

First, calculate the time that degredation of the COD in non$\mathrm{BN}$ is required:

The amount of COD in non-BN $=\mathrm{La}-4.55 * \mathrm{~L}_{\mathrm{BN}}$

Where $\mathrm{L}_{\mathrm{BN}}$ is the initial concentration of $\mathrm{BN}(\mathrm{mg} / \mathrm{L})$

Removal of this part of COD (non-BN) takes time= $\left(\mathrm{La}-4.55 * \mathrm{~L}_{\mathrm{BN}}\right) /(\mathrm{NsX})$

The time that degredation of the $\mathrm{COD}$ in $\mathrm{BN}$ is required: formula (1) - (3) 


$$
\mathrm{La} /(\mathrm{NsX})-\left(\mathrm{La}-4.55 * \mathrm{~L}_{\mathrm{BN}}\right) /(\mathrm{NsX})=4.55 * \mathrm{~L}_{\mathrm{BN}} /(\mathrm{NsX}) \text {. }
$$

The amount of $\mathrm{BN}$ is removed while removing the $\mathrm{COD}$ in stage A:

$$
=\mathrm{N}_{\mathrm{BN} 1} \mathrm{X}^{*}\left[4.55 * \mathrm{~L}_{\mathrm{BN}} /(\mathrm{NsX})\right]
$$

Where $\mathrm{N}_{\mathrm{BN} 1}$ is the $\mathrm{BN}$ removal rate while removing $\mathrm{COD}$ in stage A (mgBN/mgMLSS*d)

The time required to remove the remaining $\mathrm{BN}$ :

$$
=\left\{\mathrm{L}_{\mathrm{BN}}-\mathrm{N}_{\mathrm{BN} 1} \mathrm{X}^{*}\left[4.55 * \mathrm{~L}_{\mathrm{BN}} /(\mathrm{NsX})\right]\right\} /\left(\mathrm{N}_{\mathrm{BN} 2} \mathrm{X}\right)
$$

Where $\mathrm{N}_{\mathrm{BN} 2}$ is the the $\mathrm{BN}$ removal rate after removal of COD task is completed

$(\mathrm{mgBN} / \mathrm{mgMLSS} * \mathrm{~d})$

(3) Removal of ammonia nitrogen:

The amount of COD in non-BN is La- $4.55 * \mathrm{~L}_{\mathrm{BN}}$.

BOD value of COD in non-BN $=\left(\mathrm{La}-4.55 * \mathrm{~L}_{\mathrm{BN}}\right) * \mathrm{R}_{\mathrm{B}-\mathrm{C}}$

Where the $\mathrm{R}_{\mathrm{B}-\mathrm{C}}$ is $\mathrm{BOD} / \mathrm{COD}$ value of the COD in non-BN.

Ammonia nitrogen removal in the biochemical degradation of COD in non-BN

$$
=\left(\mathrm{La}-4.55 * \mathrm{~L}_{\mathrm{BN}}\right) * \mathrm{R}_{\mathrm{B}-\mathrm{C}} * \mathrm{R}_{\mathrm{C}-\mathrm{N}}
$$

Where the Rc-n is the ratio of the consumed ammonia nitrogen to the BOD removal of the COD in non-BN.

The amount of ammonia nitrogen in raw water: $\mathrm{L}_{\mathrm{N}}$.

Where the $\mathrm{L}_{\mathrm{N}}$ is the initial concentration of ammonia nitrogen $(\mathrm{mg} / \mathrm{L})$

Removal of residual ammonia nitrogen after removal of COD task is completed:

$$
=\mathrm{L}_{\mathrm{N}^{-}}\left(\mathrm{La}-4.55 * \mathrm{~L}_{\mathrm{BN}}\right) * \mathrm{R}_{\mathrm{B}-\mathrm{C}} * \mathrm{Rc}-\mathrm{n} .
$$

BN produces ammonia nitrogen: $\mathrm{L}_{\mathrm{BN}}$.

The amount of ammonia nitrogen produced after degradation of $\mathrm{BN}$ :

$$
=\mathrm{L}_{\mathrm{N}^{-}}\left(\mathrm{La}-4.55 * \mathrm{~L}_{\mathrm{BN}}\right) * \mathrm{R}_{\mathrm{B}-\mathrm{C}} * \mathrm{R}_{\mathrm{C}-\mathrm{N}}+\mathrm{L}_{\mathrm{BN}}
$$

The time required to remove these ammonia nitrogen:

$$
=\left[\mathrm{L}_{\mathrm{N}^{-}}\left(\mathrm{La}-4.55 * \mathrm{~L}_{\mathrm{BN}}\right) * \mathrm{R}_{\mathrm{B}-\mathrm{C}} * \mathrm{R}_{\mathrm{C}-\mathrm{N}^{+}}+\mathrm{L}_{\mathrm{BN}}\right] /\left(\mathrm{N}_{\mathrm{N}} * \mathrm{X}\right)
$$

Where the $\mathrm{N}_{\mathrm{N}}$ is the nitrifying rate of of ammonia nitrogen $\left(\mathrm{mgNH}_{3}-\mathrm{N} / \mathrm{mgMLSS} . \mathrm{d}\right)$

The time required for denitrification [19]:

$$
\left.=\mathrm{L}_{\mathrm{N}}-\left(\mathrm{La}-4.55 * \mathrm{~L}_{\mathrm{BN}}\right) * \mathrm{R}_{\mathrm{B}-\mathrm{C}} * \mathrm{R}_{\mathrm{C}-\mathrm{N}}+\mathrm{L}_{\mathrm{BN}}\right] /\left(\mathrm{N}_{\mathrm{DN}} * \mathrm{X}\right)
$$

Where the $\mathrm{N}_{\mathrm{DN}}$ is the denitrifying rate (mg total $\mathrm{N}$ needs to remove /mgMLSS. d)

\subsection{Application of Biochemical Treatment Degradation Kinetics Model of Coking Wastewater}

(1) Example: if the pollutant index of a coking wastewater is: $\quad \mathrm{COD}=3500 \mathrm{mg} / \mathrm{L}, \quad \mathrm{BN}=124 \mathrm{mg} / \mathrm{L}, \quad \mathrm{NH}_{3}-\mathrm{N}=300 \mathrm{mg} / \mathrm{L}$; $\mathrm{Q}=1100 \mathrm{~m}^{3} / \mathrm{d}$. How much volume of the biochemical reactor do you need to calculate?

Solution
(A) COD removal process:

Calculate the hydraulic retention time (HRT) required to remove COD

Assume the $\mathrm{Ns}=0.28(\mathrm{mgCOD} / \mathrm{mgMLSS} . \mathrm{d})$,

$\mathrm{X}=4000(\mathrm{mg} / \mathrm{L})$.

From formula (1),:

$$
\mathrm{HRT}=\mathrm{La} /(\mathrm{NsX})=3500 / 0.28 * 4000=3.13(\mathrm{~d})
$$

(B) Removal of $\mathrm{BN}$ process:

First, calculate the HRT that degredation of the COD in non- $\mathrm{BN}$ is required

From formula (2)

The amount of COD in non BN:

$$
\mathrm{La}-4.55 * \mathrm{~L}_{\mathrm{BN}}=3500-4.55 * 124=3500-564=2936(\mathrm{mg} / \mathrm{L})
$$

Removal of this part of COD (non-BN) requires time: according to formula (3)

$$
\left(\mathrm{La}-4.55 * \mathrm{~L}_{\mathrm{BN}}\right) /(\mathrm{NsX})=2936 /(0.28 * 4000)=2.62(\mathrm{~d})
$$

The time that degredation of the $\mathrm{COD}$ in $\mathrm{BN}$ is required: according to formula (4)

$$
\begin{gathered}
\mathrm{La} /(\mathrm{NsX})-\left(\mathrm{La}-4.55 * \mathrm{~L}_{\mathrm{BN}}\right) /(\mathrm{NsX})=4.55 * \mathrm{~L}_{\mathrm{BN}} \\
/(\mathrm{NsX})=4.55 * 124 /(0.28 * 4000)=0.51(\mathrm{~d})
\end{gathered}
$$

The amount of $\mathrm{BN}$ is removed while removing the COD: according to formula (5)

$$
\mathrm{N}_{\mathrm{BN} 1} \mathrm{X} *\left[4.55 * \mathrm{~L}_{\mathrm{BN}} / \underset{(\mathrm{Ng} / \mathrm{N})]}{=}=0.00852 * 4000 * 0.51=17.4\right.
$$

$\left(\mathrm{N}_{\mathrm{BN} 1}\right.$ takes $0.00852 \mathrm{mgBN} / \mathrm{mgMLSS}$. d)

The time required to remove the remaining $\mathrm{BN}$ : according to the formula (6)

$$
\begin{gathered}
\left\{\mathrm{L}_{\mathrm{BN}}-\mathrm{N}_{\mathrm{BN} 1} \mathrm{X} *\left[4.55 * \mathrm{~L}_{\mathrm{BN}} /(\mathrm{NsX})\right]\right\} /\left(\mathrm{N}_{\mathrm{BN} 2} \mathrm{X}\right)= \\
{[124-17.4] / 0.0224 * 4000=1.19(\mathrm{~d})}
\end{gathered}
$$

$\left(\mathrm{N}_{\mathrm{BN} 2}\right.$ takes $\left.0.0224 \mathrm{mgBN} / \mathrm{mgMLSS} . \mathrm{d}\right)$

(C) Removal of ammonia nitrogen:

The BOD value of COD for non-BN: according to formula (7)

$$
\left(\mathrm{La}-4.55 * \mathrm{~L}_{\mathrm{BN}}\right) * \mathrm{R}_{\mathrm{B}-\mathrm{C}}=2936 * 0.509=1494(\mathrm{mg} / \mathrm{L})
$$

$\mathrm{R}_{\mathrm{B}-\mathrm{C}}$ takes value of 0.509

Ammonia nitrogen removal in the biochemical degradation of COD for non-BN: according to formula (8)

$$
\begin{gathered}
\left(\mathrm{La}-4.55 * \mathrm{~L}_{\mathrm{BN}}\right) * \mathrm{R}_{\mathrm{B}-\mathrm{C}} * \mathrm{Rc}-\mathrm{n}=1494 * 0.043=64(\mathrm{mg} / \mathrm{L}) \\
\mathrm{R}_{\mathrm{C}-\mathrm{N}} \text { takes value of } 0.043
\end{gathered}
$$

The amount of ammonia nitrogen remaining after removal of COD: according to formula (9)

$$
\mathrm{L}_{\mathrm{N}^{-}}\left(\mathrm{La}-4.55 * \mathrm{~L}_{\mathrm{BN}}\right) * \mathrm{R}_{\mathrm{B}-\mathrm{C}} * \mathrm{R}_{\mathrm{C}-\mathrm{N}}=300-64=236(\mathrm{mg} / \mathrm{L})
$$

The amount of ammonia nitrogen produced after degradation of BN: according to formula (10) 
$\mathrm{LN}-\left(\mathrm{La}-4.55 * \mathrm{~L}_{\mathrm{BN}}\right) * \mathrm{R}_{\mathrm{B}-\mathrm{C}} * \mathrm{R}_{\mathrm{C}-\mathrm{N}}+\mathrm{L}_{\mathrm{BN}}=236+124=360(\mathrm{mg} / \mathrm{L})$

The time required to remove these ammonia nitrogen: according to formula (11)

$$
\begin{gathered}
{\left[\mathrm{L}_{\mathrm{N}}-\left(\mathrm{La}-4.55 * \mathrm{~L}_{\mathrm{BN}}\right) * \mathrm{R}_{\mathrm{B}-\mathrm{C}} * \mathrm{R}_{\mathrm{C}-\mathrm{N}}+\mathrm{L}_{\mathrm{BN}}\right] /\left(\mathrm{N}_{\mathrm{N}} * \mathrm{X}\right)=} \\
360 /(0.0194 * 4000)=4.64(\mathrm{~d})
\end{gathered}
$$

$\mathrm{N}_{\mathrm{N}}$ takes value of $0.0194\left(\mathrm{mgNH}_{3}-\mathrm{N} / \mathrm{mgMLSS} . \mathrm{d}\right)$

Time required for denitrification: according to formula (12)

$\left[\mathrm{L}_{\mathrm{N}}-\left(\mathrm{La}-4.55 * \mathrm{~L}_{\mathrm{BN}}\right) * \mathrm{R}_{\mathrm{B}-\mathrm{C}} * \mathrm{R}_{\mathrm{C}-\mathrm{N}}+\mathrm{L}_{\mathrm{BN}}\right] /\left(\mathrm{N}_{\mathrm{DN}} * \mathrm{X}\right)=$ $360 /(0.0325 * 4000)=2.77(\mathrm{~d})$

$\mathrm{N}_{\text {DN }}$ takes value of 0.0325 (mg total $\mathrm{N} / \mathrm{mgMLSS}$. d)

The total hydraulic retention time is:

$$
3.13(d)+1.19(d)+4.64(d)+2.77(d)=11.73(d)
$$

Effective volume of biochemical tank: $\mathrm{V}=1100 * 11.77=12947 \mathrm{~m}^{3}$.

(2) Example: Other conditions are such as 4.6.1 if the $\mathrm{BN}$ is ignored. How much volume of the biochemical reactor do you need to calculate?

Solution

(A) COD removal process:

Calculate the hydraulic retention time (HRT) required to remove COD

Assume the $\mathrm{Ns}=0.28$ (mgCOD/mgMLSS.d), $\mathrm{X}=4000$ (mg/L).

From formula (1),

$$
\mathrm{HRT}=\mathrm{La} /(\mathrm{NsX})=3500 / 0.28 * 4000=3.13(\mathrm{~d})
$$

(B) Removal of ammonia nitrogen:

The BOD value of COD

$$
\mathrm{L}_{\mathrm{a}} * \mathrm{R}_{\mathrm{B}-\mathrm{C}}=3500 * 0.509=1782(\mathrm{mg} / \mathrm{L})
$$

$R_{B \text { - C }}$ takes value of 0.509

Ammonia nitrogen removal while the biochemical degradation of COD:

$$
\begin{gathered}
\mathrm{La}^{*} \mathrm{R}_{\mathrm{B}-\mathrm{C}} * \mathrm{R}_{\mathrm{C}-\mathrm{N}}=1782 * 0.043=76(\mathrm{mg} / \mathrm{L}) \\
\mathrm{R}_{\mathrm{C}-\mathrm{N}} \text { takes value of } 0.043
\end{gathered}
$$

The amount of ammonia nitrogen remaining after removal of COD:

$$
\mathrm{L}_{\mathrm{N}}-\mathrm{La} * \mathrm{R}_{\mathrm{B}-\mathrm{C}} * \mathrm{R}_{\mathrm{C}-\mathrm{N}}=300-76=224(\mathrm{mg} / \mathrm{L})
$$

The time required to remove these ammonia nitrogen: according to formula (11)

$$
\begin{gathered}
{\left[\mathrm{L}_{\mathrm{N}}-\mathrm{La} * \mathrm{R}_{\mathrm{B}-\mathrm{C}} * \mathrm{R}_{\mathrm{C}-\mathrm{N}}\right] /\left(\mathrm{N}_{\mathrm{N}} * \mathrm{X}\right)=224 /(0.0194 * 4000)} \\
=2.89(\mathrm{~d})
\end{gathered}
$$

$\mathrm{N}_{\mathrm{N}}$ takes value of $0.0194\left(\mathrm{mgNH}_{3}-\mathrm{N} / \mathrm{mgMLSS} . \mathrm{d}\right)$

Time required for denitrification: according to formula (12)

$$
\begin{gathered}
{\left[\mathrm{L}_{\mathrm{N}}-\mathrm{La}^{*} \mathrm{R}_{\mathrm{B}-\mathrm{C}} * \mathrm{R}_{\mathrm{C}-\mathrm{N}}\right] /\left(\mathrm{N}_{\mathrm{DN}} * \mathrm{X}\right)=224 /(0.0325 * 4000)} \\
=1.72(\mathrm{~d})
\end{gathered}
$$

$\mathrm{N}_{\text {DN }}$ takes value of 0.0325 (mg total $\mathrm{N} / \mathrm{mgMLSS}$. d)

The total hydraulic retention time is:

$$
3.13(d)+2.89(d)+1.72(d)=7.74(d)
$$
$\mathrm{m}^{3}$.

Effective volume of biochemical tank: $\mathrm{V}=1100 * 7.74=8514$

As can be seen from 4.6.1 and 4.6.2, BN's role in biochemical processes cannot be ignored.

\section{Conclusion}

Through a large number of experimental studies, it is found that there are three stages of degradation mechanism in the biochemical degradation process of coking wastewater. In the first stage of biochemistry is the removal of a large amount of organic pollutants, so that the strong smell of the wastewater is removed while most of the COD is removed. In the second stage of biochemistry is the removal of substances that produce ammonia nitrogen $(\mathrm{BN})$. These increases the ammonia nitrogen in the waste water. In the third stage of biochemistry is degradation of ammonia nitrogen, so that ammonia nitrogen meets the emission standard. And there's a new concept here which is BN. It refers to a group of substances that will produce ammonia nitrogen in a biochemical process, and it affects the process of biochemical treatment of coking wastewater. The first stage affects the second stage. If COD is not degraded to a certain extent in the first stage, it will suppress the second stage, and it will be difficult to start the second stage; The second stage affects the third stage. And if $\mathrm{BN}$ is not degraded to a certain degree in the second stage, it will suppress the third stage, and it will be difficult to start the third stage.

The dynamic mathematical model of biochemical degradation of coking wastewater was proposed. The mathematical model consists of 12 formulas, one for the first stage, five for the second stage and six for the third stage. The hydraulic retention time of each stage of biochemical reaction tank can be calculated by the formulas. It can be seen from the selected examples that $\mathrm{BN}$ plays an important role in the biochemical degradation of coking wastewater.

\section{Acknowledgements}

The authors gratefully acknowledge support from the relative projects of the bio-treatment of coking wastewater.

\section{Author Disclosure Statement}

No competing financial interests exist.

\section{References}

[1] The preparation group of the standards for the emission of pollutants in coking industry (2010). the Preparation Document of the Standards for the Emission of Pollutants in Coking Industry (Chinese). Beijing: China Environmental Science Press. 
[2] Kong Lingdong, and Jiang Chengchun (1994). Treatment of coking wastewater and determination of organic pollutants in wastewater (Chinese). Environmental engineering. 12(4), 3.

[3] Kim Young Mo, Park Donghee, Lee Dae Sung, et al. (2008). Inhibitory effects of toxic compounds on nitrification process for cokes wastewater treatment. Journal of Hazardous Materials, 152(3), 915-921.

[4] Wang Chunrong, Gao Zhenfeng, Wang Jianbing, Cheng Fanglin (2013). Research on the phenol-degradation strain from coking wastewater treatment system and its kinetics. Industrial Water Treatment (Chinese), 33(6), 25-28.

[5] Dev Raj Joshi, Yu Zhang, Zhe Tian, Yingxin Gao, Min Yang, (2016). Performance and microbial community composition in a long-term sequential anaerobic-aerobic bioreactor operation treating coking wastewater. Applied Microbiology and Biotechnology, 100(18), 8191-8202.

[6] PENG Pai, ZHU Xi-kun, LI Xiao-ming, YANG De-yu, LI Li, (2016). Pilot test on the application of environmental sludge bacteria agent to coking wastewater. Environmental Engineering (Chinese), 34(6), 41-45.

[7] Cui Chongwei, Ma Fang, Zhang Yanmin, et al. (2002). Investigation into the process modification of Hayi coal gasification wastewater treatment plant. Journal of Harbin University of Civil Engineering and Architecture (Chinese), 35(5), 26-29.

[8] Li Huiqiang, Han Hongjun, Du Maoan, et al. (2011). Removal of phenols, thiocyanate and ammonium from coal gasification wastewater using moving bed biofilm reactor. Bioresource Technology, 102(7), 4667-4673.

[9] Zhao Qian, Han Hongjun, Hou Baolin, et al. (2014). Nitrogen removal from coal gasification wastewater by activated carbon technologies combined with short-cut nitrogen removal process. Journal of Environmental Sciences, 26(11), 2231-2239.
[10] Zhang M, Jin T N, Qian Y, et al. (1997). Comparison Between Anaerobic-anoxic-oxic and Anoxic-oxic System for Coke Plant Wastewater Treatment. Journal of Environment Engineering, 123(9), 876-883.

[11] Zhou Xin, Li Yaxin, Zhao Yi, et al. (2013). Pilot-scale anaerobic/anoxic/oxic/oxic biofilm process treating coking wastewater. Journal of Chemical Technology and Biotechnology, 88(2), 305-310.

[12] Maranón E, Vázquez I, Rodríguez J, et al. (2008). Treatment of coke wastewater in a sequential batch reactor (SBR) at pilot plant scale. Bioresource Technology, 99(10), 4192-4198.

[13] LIU Cui-ping, ZHAO Jie, YUE Ying-li, (2016). The Technology Application of A1-A2-O in the Treatment of Coking Waste Water. Science and Technology of Baotou Steel (Chinese), 42(6), 88-91.

[14] Jin Tao Su Zhiguang Ding Zuo, (2016). Design and operation of coking waste water treatment plant. Fuel \& Chemical Processes (Chinese), 47(1), 57-59.

[15] Ramalho R. S. (1977). Introduction to Wasteater Treatment Processes. New York: Academic Press, Inc. Ltd.

[16] Mandt Mikkel G., and Bell Bruce A. (1982). Oxidation Ditches in Wastewater Treatment. Michigan: Ann Arbor Science Publishers.

[17] Lawrence, A. W., and McCarthy, P. L. (1970). Unified Basis for Biological Treatment Design and Operation. J. Sanit. Eng. Div. 96, 757.

[18] Eckenfelder, W. Wesley, Jr, and Musterman, J. L., Jiang, Wenchuo, translator (1997). Activated Sludge Treatment for Industrial Wastewater (Chinese). Beijing: China Construction Industry Press.

[19] Eckenfelder, W. Wesley., Jr, (1989). Industrial Water Pollution Control. New York: McGraw-Hill Book Co. 